\title{
Profile of Suicide Attempts in Adolescents; Demographic Features, Reasons and Risk Factors
}

\author{
Adölesanlardaki İntihar Girişimlerinin Profili; Demografik Özellikler, \\ Nedenler ve Risk Faktörleri
}

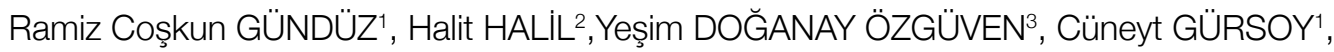 \\ Cüneyt KARAGÖL ${ }^{1}$, Atilla ÇiFCi ${ }^{1}$, Ganime AYAR ${ }^{1}$, Seher ÖZGÜN ${ }^{4}$
}

\begin{abstract}
${ }^{1}$ Ankara Child Health and Diseases Hematology Oncology Training and Research Hospital, Ankara, Turkey
2Zekai Tahir Burak Women's Health Education and Research Hospital, Department of Child Health and Diseases, Ankara, Turkey

${ }^{3}$ Ankara Child Health and Diseases Hematology Oncology Training and Research Hospital, Patient Rights Unit, Ankara, Turkey

${ }^{4}$ Ankara Child Health and Diseases Hematology Oncology Training and Research Hospital, Children's Emergency Department,

Ankara, Turkey
\end{abstract}

\begin{abstract}
Objective: Suicide has dramatically increased in recent years and has become the second leading cause of death in adolescents. Poisoning due to consumption of drugs and toxic materials is the second leading route of suicide attempts among adolescents.
\end{abstract}

Material and Methods: We evaluated the demographic features, risk factors and reasons of suicide in 322 adolescents who attempt suicide by using drugs and poisonous materials.

Results: The mean $\pm S D$ age of the patients was $15.37 \pm 1.61$. The rate of suicide attempt was more common in females than males (83.5\% vs. 16.5\%). Personal factors were the major causes underlying adolescent suicide (in $72.1 \%$ of females and $79.2 \%$ of males $p=0.284)$. The most common personal factor was adolescent development problems in both sexes (28.57\%). Multiple factors were found in $45.4 \%$ of female and $35.8 \%$ of male adolescents $(p=0.202)$.

Conclusion: Clarifying risk factors and identifying adolescents at high risk in our population will help in developing effective strategies for the prevention of adolescent suicide.

Key Words: Adolescents, Attempts, Behavior, Children, Risk factors, Suicide

\section{ÖZET}

Amaç: Son yıllarda intihar girişimi dramatik olarak artmaktadır ve adölesan ölümlerinin ikinci en sık nedeni haline gelmiştir. İlaç ve toksik madde kullanımına bağlı zehirlenme adölesanlardaki intihar girişimlerinin ikinci en sık aracıdır.

Gereç ve Yöntemler: İlaç ve zehirli madde kullanarak intihar girişiminde bulunan 322 adölesanın demografik özellikleri, intihar nedenleri ve intihar için risk faktörleri incelendi.

Bulgular: Hastaların ortalama \pm SD yaşı $15.37 \pm 1.61$ 'di. İntihar girişimi oranı kızlarda erkeklere göre daha fazlaydı (\%83.5 vs \%16.5). Adölesan intiharlarının çoğunluğunda altta yatan neden kişisel faktörlerdi (kızlarda \%72.1 ve erkeklerde \%79.2 oranında, $p=0.284)$. Her iki cinsiyetteki en sık kişisel faktör adölesan gelişim problemleriydi (28.57\%). Çoklu faktörler kızların \%45.4, erkeklerin ise \%35.8'inde bulunmaktaydı ( $\mathrm{p}=0.202)$.

Sonuç: Risk faktörlerinin aydınlatılması ve toplumdaki yüksek riskli adölesanların belirlenmesi, adölesan intiharlarının önlenmesi için efektif stratejilerin geliştirilmesine yardımcı olacaktır.

Anahtar Sözcükler: Adölesan, Girişim, Davranış, Çocuk, Risk faktörleri, İntihar

\section{INTRODUCTION}

Adolescent suicide is still an important public health problem all over the world. It is defined as the tragic action of killing oneself intentionally and voluntarily. Suicidal ideation refers to thoughts of harming or killing oneself. Attempted suicide is a non-fatal, self-destructive action with intention to die. If this action is completed and proceeds to death, it is defined as suicide behavior. Suicidality refers to all suicide-related behaviors and thoughts including completing or attempting suicide $(1,2)$. 
Suicidal thoughts and suicidal behaviours start developing at the early adolescence stage and increase dramatically to reach their peak at late adolescence and early adulthood (3). Transition from ideation to plan and attempt occurs in 60\% of cases within the first year after ideation onset (4).

The World Health Organisation (WHO) has reported that suicide is among the three leading causes of death for all ages. In recent years, the number of adolescent deaths due to suicide has been increased dramatically and become the secondleading cause of death in the 10-24 years age group (1,5-7).

Many factors affect adolescent suicide. Personal risk factors include male gender, mood disorders, psychosis, suicidal thoughts, problems with alcohol or other drug abuse, sexual orientation, posttraumatic stress disorder, panic attacks and difficulties in school. Family risk factors include family history of suicide or suicide attempts, parental mental health problems, impaired parent-child relationship and arguments with parents $(7,8,11)$. Social and environmental risk factors include the presence of drugs or chemicals and easy access to firearms at home $(7,10-11)$. They also include factors related to social isolation especially in homeless children, presence of emotional difficulties, and stressful life events that affect the mood of the adolescent (8-11). Frequently, suicidal behaviours in adolescents appear to be the result of adverse life sequences in which multiple risk factors from these domains combine to increase risk of suicidal attempt. When multiple risk factors are present, the risk of suicide increases further (8). These risk factors should be investigated at both acute care and routine care visits. Knowledge of risk factors and usage of appropriate techniques may assist in identifying potential suicidal adolescents (12).

Firearms, hanging, and poisoning are the most frequent methods of attempting suicide among adolescents $(5,13)$.

Suicidal thoughts are reported to be more common in adolescent girls than in adolescent boys $(5,13)$. In Western societies, more girls attempt suicide than boys. However, boys are 3-4 times more successful than girls in completing their attempt $(5,14)$.

Suicidal behavior tends to be recurrent (17). Girls are at higher risk of repetition than boys. More girls attempt, but more boys complete suicide $(14,16)$. Recurrent suicide attempts are associated with higher rates of psychiatric problems like major depression, hopelessness and emotional problems $(15,16)$.

The main target of effective prevention of adolescent suicide is to reduce the risk factors. Effective treatment of underlying psychiatric disorders that lead to suicidal feeling and behavior is essential in preventing child and adolescent suicides (5).

The aim of our present study was to identify the profile of adolescent suicide and clarify the features, risk factors and reasons of underlying attempts.

\section{MATERIALS and METHODS}

This cross-sectional retrospective study was conducted at the emergency service of Ankara Pediatric Hematology and Oncology Research and Training Hospital between March 2012 and December 2013. Our data were collected from hospital records and were evaluated by medical doctors. Three hundred and twenty two adolescents who ingested drugs or toxic materials for a suicide attempt were included in our study. Suicide attempts due to firearms, hanging and jumping off high places were excluded from our study.

Hospital record forms included gender, age, marital status, profession and educational status of service users. They also included the types and reasons of suicide, history of previous suicide attempt, family history of suicide, history of psychological diagnosis or treatment in the past 6 months and psychiatric consultations before discharge.

We grouped risk factors as follows: - Family problems, violence, conflicts and death of a relative were grouped as family factors. 2- Economic problems, chronic disease, alcohol and drug abuse, sexual problems, sexual abuse, test anxiety, psychological problems, adolescent development problems and emotional difficulties were grouped as personal factors. 3- Social isolation, homelessness, rape, unwanted marriage, communication problems, problems at work and school problems were grouped as social and environmental factors. Those who had more than one factor were grouped as multifactorial.

The study was approved by the Medical Ethics Committee of Ankara Pediatric Hematology and Oncology Research and Training Hospital.

The SPSS (Statistical Package for Social Sciences) for Windows 18.0 programme was used for statistical analysis. All data were entered by social workers into a database and were verified by a second independent person. The variables were investigated using visual (histograms, probability plots) and analytical methods to determine whether or not they were normally distributed. Data were presented as mean \pm S.D. for normally distributed variables) and as median, (maximum-minimum) for skew distributed continuous variables. Categorical variables were shown as frequencies. Pearson's $x 2$ method was performed for categorical variables for univariate analysis. Independent Samples $t$ test was used for normally distributed variables and the Mann-Whitney $U$ test for not normally distributed variables. Two-sided values of $p<0.05$ were considered as statistically significant.

\section{RESULTS}

A total of 322 patients consisting of 269 females (83.5\%) and 53 males (16.5\%) were included in this study. The mean \pm SD age was $15.3 \pm 1.61$ in females and $15.6 \pm 1.58$ in males. 
Demographic properties of the patients are presented in Table I.

Distribution of factors according to gender is presented in Table II. The major factors underlying adolescent suicide were personal factors in $72.1 \%$ of the females and $79.2 \%$ of the males $(p=0.284)$. Family-related factors were more common in females than males $(59.9 \%$ vs. $43.4 \%, p=0.027)$ and arguments between parents and family conflicts were the prominent family factors. A multifactorial etiology was found in $45.4 \%$ of female and $35.8 \%$ of male adolescents ( $p=0.202$ ). Personal factors were accompanied by family-related factors in $49 \%$ of females and $35.7 \%$ of males and environmental factors in $12.9 \%$ of females and $11.9 \%$ of males. Personal and familyrelated psychopathological factors are shown in Table III.

\section{DISCUSSION}

Adolescent suicide is still a global public health problem. In our present study, we evaluated the demographic features, predisposing risk factors and reasons underlying adolescent suicide attempts.

Consistent with past population-based studies of adolescent suicide, we found that the rate of suicide attempt was higher in female than in male adolescents (83.5\% vs. $16.5 \%)$ (14$16,19,20)$. Strandheim et al. (21) administered a questionnaire about suicidal thoughts and found that out of 2399 students, 408 students (17\%) reported having had suicidal thoughts; the prevalence was $19.5 \%$ in girls and $14.2 \%$ in boys. However, Lewinsohn et al. (15), in a previous study on adolescents with major depressive disorders, found that by the age of 19 years the suicide attempt hazard rate for female adolescents dropped to a level comparable with that of male adolescents. They also deduced that the gender differences may be related to different underlying causes and the fact that depressive states and anxiety are less frequent among boys than girls (15).

A higher proportion of our patients were young (mean age \pm SD $15.31 \pm 1.61$ years), females $(n=269 ; 83.5 \%$ and unmarried $(n=312 ; 96.9 \%)$. These findings are consistent with Nock et al.'s study that was conducted in 17 countries and found that the majority of suicide attempts were among unmarried, young females (4). They also found that across all countries, less educated adolescents and those complaining of mental disorders were more prone to suicide attempts than others. Unlike that study, the majority of our adolescents were high school students ( $n=181 ; 56.2 \%)$, and had no history of previous psychological diagnosis, and mental or mood disorders $(n=297$; 92.2\%)

We also found that family-related factors were more common in females (59.9\% vs. $43.4 \%, p=0.027)$. Arguments with parents and family conflicts were the prominent family-related risk factors in our present study. Spirito et al. (9) found a significant degree of individual and family dysfunction among adolescents attempting suicide and a strong evidence for the specificity of this dysfunction to suicide attempts was found in those complaining of family conflicts. Breton et al. (22) reported that fight with parents and the end of a relationship were the most common triggers for suicidality among adolescents.

Gould et al reported that more than 90\% of youth have had at least one major psychiatric disorder before their suicide attempt (6). In the same field, Beautrais et al. (13) Brent et al. (11) and Groholt et al. (24) reported that an average of $60 \%$ of

Table I: Demographic properties of adolescents.

\begin{tabular}{|l|l|c|}
\hline $\begin{array}{l}\text { Properties of } \\
\text { adolescents }\end{array}$ & & Number (\%) \\
\hline Sex & Female & $269(83.5)$ \\
& Male & $53(16.5)$ \\
\hline Age groups (years) & $13-12$ & $17(5.3)$ \\
& $15-18$ & $137(42.5)$ \\
\hline \multirow{2}{*}{ Educational status } & No education & $168(52.2)$ \\
& Elementary school & $2(0.6)$ \\
\hline \multirow{2}{*}{ Marital status } & High school & $181(56.2)$ \\
\hline \multirow{2}{*}{ Employment } & Married & $10(3.1)$ \\
\hline \multirow{2}{*}{ Level of personal or } & Unmarried & $312(96.9)$ \\
\hline family income & Employed & $28(8.7)$ \\
\hline & Unemployed & $294(91.3)$ \\
\hline
\end{tabular}

Table II: Distribution of factors according to gender.

\begin{tabular}{|l|c|c|c|}
\hline Factors & Female & Male & P value \\
\hline Family-related factors & $59.9 \%$ & $43.4 \%$ & 0.027 \\
\hline Personal factors & $72.1 \%$ & $79.2 \%$ & 0.284 \\
\hline Environmental factors & $15.6 \%$ & $17.0 \%$ & 0.803 \\
\hline Multifactorial & $45.4 \%$ & $35.8 \%$ & 0.202 \\
\hline
\end{tabular}

Table III: Psychopathological properties of adolescents.

\begin{tabular}{l|c|c|}
\hline Properties of adolescents & & Number (\%) \\
\hline $\begin{array}{l}\text { History of previous suicidal } \\
\text { attempt }\end{array}$ & Yes & $56(17.4)$ \\
\hline History of previous & Yes & $266(82.6)$ \\
psychological diagnosis & No & $297(7.8)$ \\
\hline $\begin{array}{l}\text { Psychotherapy in past 6 } \\
\text { months }\end{array}$ & Yes & $63(19.6)$ \\
\hline Family history of suicide & No & $259(80.4)$ \\
& Yes & $24(7.5)$ \\
\hline & No & $298(92.5)$ \\
\hline
\end{tabular}


young adolescent suicide victims had psychopathology $(8,23)$. Depressive disorders were found in $49 \%$ to $64 \%$ of victims $(8,25)$. In our present study, we found that the major factors underlying adolescent suicide were personal factors in $72.1 \%$ of females and $79.2 \%$ of males $(p=0.284)$ and adolescent development problems were the major factors in both sexes (28.57\%). Unlike the previous studies, the history of previous psychological diagnosis and psychotherapy in past 6 months were found only in $7.8 \%$ and $19.6 \%$ respectively.

Miranda et al. (17) reported that suicidal behaviour in youth tends to repeat itself, and up to $42 \%$ of adolescents who attempted suicide will make another attempt over the subsequent 2 years. The same author deduced from another study that recurrent suicide attempts were associated with higher rates of psychiatric problems like major depression, hopelessness and emotional problems (18). Boeninger et al. (16) found that girls are at higher risk of suicide repetition than boys (17). We found that only $17.4 \%$ adolescent had a history of previous suicidal attempts, and girls $(87.5 \%$ vs. $12.5 \% p=$ 0.379 ) predominate boys. $78.6 \%$ of those adolescents had personal factors underlying their recurrent attempts, but unlike the previous studies only $25 \%$ of recurrent attempts had a history of previous psychological diagnosis, and about $53.6 \%$ of cases had a history of psychotherapy in the past 6 months.

Multiple factors were found in $45.4 \%$ of female and $35.8 \%$ of male adolescents $(p=0.202)$. Personal factors were accompanied by family factors in $49 \%$ of females and $35.7 \%$ of males and environmental factors in $12.9 \%$ of females and $11.9 \%$ of males. Evidence from past research supported that multiple factors rather than any single condition are strongly associated with suicide attempts and when multiple risk factors are present, the risk of suicide increased further (8).

In our present study, we included suicide attempts due to consumption of drugs and toxic materials and excluded those due to hanging, firearms and jumping off high places. This was due to the fact that traumatic patients are directly referred to trauma emergency services at other hospitals in Ankara. Nevertheless, data about psychiatric consultations provided to patients before discharge are limited and the hospital records were incomplete. Therefore, the information that we have found was not suitable for any statistical analysis. The investigation of these limitations and other factors will provide important direction and guidance for future research.

In our study, we found that suicidal attempts were more frequent among adolescent girls than boys and most strongly associated with personal factors in both sexes. Family-related factors were more prominent in girls than boys. Multiple factors rather than a single factor were strongly associated with increased suicide attempts in more than one third of our patients. Clarifying risk factors, identifying the potential suicidal adolescents, and improving access to health services and psychological support units are promising strategies for the prevention of adolescent suicide.

\section{REFERENCES}

1. O'Carroll PW, Berman AL, Maris RW, Moscicki EK, Tanney BL, Silverman MM. Beyond the Tower of Babel: A nomenclature for suicidology. Suicide and Life Threat Behavi 1996;26:237-52.

2. Diclemente RJ, Hansen WB, Ponton LE. Handbook of Adolescent Health Risk Behavior Plenum Press 1996: 193-4.

3. Fergusson DM, Lynskey MT. Suicide attempts and suicidal ideation in a birth cohort of 16-year-old New Zealanders. J Am Acad Child Adolesc Psychiatry 1995; 34:1308-17.

4. Nock MK, Borges G, Evelyn J, Bromet EJ, Alonso J, Angermeyer $\mathrm{M}$, et al. Cross-national prevalence and risk factors for suicidal ideation, plans and attempts. Br J Psychiatry 2008;192:98-105.

5. American Academy of Child and Adolescent Psychiatry (AACAP). Practice parameter for the assessment and treatment of children and adolescents with suicidal behaviour. J Am Acad Child Adolesc Psychiatry 2001; 40: 24-51.

6. Gould MS, Greenberg T, Velting DM, Shaffer D. Youth suicide risk and preventive interventions: A review of the past 10 years. J Am Acad Child Adolesc Psychiatry 2003;42:386-405.

7. Bridge AJ, Goldstein TR, Brent DA. Adolescent suicide and suicidal behavior. J Child Psychol Psychiatry 2006;47:372-94.

8. Beautrais AL. Risk factors for suicide and attempted suicide among young people. Aust N Z J Psychiatry 2000;34:420-36.

9. Spirito A, Brown L, Overholser J, Fritz G. Attempted suicide in adolescence: A review and critique of the literature. Clin Psychol Review 1989;9:335-63.

10. Brent DA. Risk factors for adolescent suicide and suicidal behavior: Mental and substance abuse disorders, family environmental factors, and life stress. Suicide Life Threat Behav 1995;25:52-63.

11. Brent DA, Perper JA, Goldstein CE, Kolko DJ, Allan MJ, Allman CJ, et al. Risk factors for adolescent suicide: A comparison of adolescent suicide victims with suicidal inpatients. Arch Gen Psychiatry 1988;45:581-88.

12. Kostenuik M, Ratnapalan M. Approach to adolescent suicide prevention. Can Fam Physician 2010;56:755-60.

13. Beautrais AL. Methods of youth suicide in New Zealand: Trends and implications for prevention. Aust N Z J Psychiatry 2000;34:413-19.

14. Cantor $C$, Neulinger $K$. The epidemiology of suicide and attempted suicide among young Australians. Aust N Z J Psychiatry 2000:34;370-87.

15. Lewinsohn PM, Rohde P, Seeley JR, Baldwin CL. Gender differences in suicide attempts from adolescence to young adulthood. J Am Acad Child Adolesc Psychiatry 2001; 40: 427-34.

16. Boeninger DK, Masyn KE, Feldman BJ. Sex differences in developmental trends of suicide ideation, plans, and attempts among European American adolescents. Suicide Life Threat Beha 2010; 40: 451-64.

17. Miranda R, De Jaegere E, Restifo K. Longitudinal follow- up study of adolescents who report a suicide attempts: Aspects of suicidal behavior that increase risk of a future attempt. Depress Anxiety 2014; 31: 19-26.

18. Miranda R, Scott M, Hicks R, Conger R. Suicide attempt characteristics, diagnoses, and future attempts: Comparing multiple attempters to single attempters and ideators. J Am Acad Child Adolesc Psychiatry 2008;47: 32-40.

19. Pelkonen M, Marttunen M. Child and adolescent suicide: Epidemiology, risk factors, and approaches to prevention. Drugs 2003; 5: 243-65. 
20. Canetto SS. The gender paradox in suicide. Suicide Life Threat Behav 1998;28:1-23.

21. Strandheim A, Bjerkeset O, Gunnell D, Bjornelv S, Holmen TL, Bentzen http://bmjopen.bmj.com/content/4/8/e005867.long - aff-2 N. Risk factors for suicidal thoughts in adolescence: A prospective cohort study: The Young-HUNT study. BMJ Open 2014; 4: e005867. Accessed October 172014.

22. Breton JJ, Boyer R, Bilodeau H, Raymond S, Joubert N, Nantel MA. Is evaluative research on youth suicide programs theorydriven? The Canadian experience. Suicide Life Threat Behav 2002; 32: 176-90.
23. Brent DA, Baugher M, Bridge J, Chen T, Chiappetta L. Age and sex related risk factors for adolescent suicide. J Am Acad Child Adolesc Psychiatry 1999; 38:1497-505.

24. Groholt B, Ekeberg O, Wichstrom L, Haldorsen T. Suicide among children and younger and older adolescents in Norway: A comparative study. J Am Acad Child Adolesc Psychiatry 1998; 37: 473-81.

25. Marttunen MJ, Aro HM, Henriksson MM, Lonnqvist JK. Mental disorders in adolescent suicide. Arch Gen Psychiatry 1991;48: 834-39. 